http://dx.doi.org/10.12775/szhf.2013.052

\title{
Czy mogę poznać innego?* Problem relacji międzypodmiotowych w filozofii Jeana Paula Sartre’a
}

Nie ulega żadnej wątpliwości, że zagadnienie relacji między jednym a drugim podmiotem $^{1}$ (sujet) jest w myśli Sartre’a zagadnieniem kluczowym. Trzon koncepcji francuskiego myśliciela opiera się na bardzo ważnym stwierdzeniu,

* W niniejszej pracy wszystkie zaimki osobowe: „ja” (je), „ty” (tu), oraz określenia typu „inny” (autre), toż-samy (le même) będę pisać małą literą, gdyż pisane wielką - zarówno w języku polskim, jak i francuskim - są uznawane za błąd ortograficzny. Czyni tak Sartre w swej najważniejszej pracy Byt i nicość. W przypadku filozofii Emmanuela Levinasa problem jest bardziej złożony. W dziele Całość i nieskończoność wyżej wymienione przeze mnie zaimki pisane są zarówno wielką, jak i małą literą. Levinas nie jest w tej kwestii konsekwentny. Słowo „inny” pisane wielką literą najprawdopodobniej wskazuje nam, że chodzi o innego człowieka. Sytuacja ulega zmianie w pracy Inaczej niż być lub ponad istotą, w której pisanie zaimków wielką literą ma niejako wskazywać, że pod postacią "Innego” ukrywa się Bóg. W swoim artykule będę co prawda nawiązywać do wątków filozofii Levinasa, ale moim celem jest ujednolicenie terminologii bez wprowadzania zbędnego zamieszania.

${ }^{1} \mathrm{~W}$ języku francuskim słowo „podmiot” tłumaczone jest jako sujet. Jednym ze znaczeń słowa sujet jest „temat”. To tłumaczenie oddaje gramatyczny charakter słowa „podmiot”, odnoszący się do imiennej części zdania. W niniejszym artykule chodzi mi o inne rozumienie. Mam tu na myśli opisaną przez Kanta podmiotowość rozumianą jako pewna jednostkowa osobowość psychologiczna, na którą składają się wszystkie następujące w czasie, a dające się uchwycić i skumulować przeżycia bycia samym sobą. W tym sensie synonimem tak pojmowanej podmiotowości będzie na przykład indywidualność (individualité) czy jednostkowość (personnalité). 
że owa relacja nie ma charakteru poznawczego, lecz egzystencjalny. Istota spotkania polega tu na doświadczeniu samej inności drugiego człowieka, zachodzącym poprzez wpływ, jaki wywiera on na moje własne istnienie. Poznanie czy też jakakolwiek wiedza na temat innego amortyzowałaby wpisany $\mathrm{w}$ istotę spotkania wstrząs i zaskoczenie ${ }^{2}$.

W kontekście moich rozważań ważny będzie wprowadzony przez Sartre’a termin „spojrzenie” (le regard), wiążący się z niemożnością odkrycia tego, co inny o mnie myśli w momencie, gdy na mnie patrzy.

Główny cel filozofii Sartre’a stanowi odnalezienie istoty człowieczeństwa, dlatego kwestią kluczową staje się dla francuskiego myśliciela opis ludzkiej podmiotowości oraz relacji międzypodmiotowych. Jednakże w celu poznania ludzkiej natury nie należy, jak mogłoby się wydawać, korzystać z narzędzi psychologii. Istotę tego problemu przedstawia Sartre w jednym ze swoich pierwszych dzieł Szkic o teorii emocji, gdzie krytykuje współczesną mu psychologię, w odniesieniu do której stwierdza, że oddzielając się od filozofii stała się nauką matematyczno-przyrodniczą.

Psychologia jest nauką, która dąży do tego, aby być pozytywna, to znaczy, że chce czerpać swoje wnioski wyłącznie $\mathrm{z}$ doświadczenia. Z pewnością nie żyjemy już w czasach asocjacjonistów i współcześni psycholodzy nie bronią się przed zadawaniem pytań i dokonywaniem interpretacji. Ale do przedmiotu badań chcą podchodzić w taki sposób, jak fizyk do obiektu swoich badań3.

Psycholog skupia się tylko na faktach, które po zgromadzeniu i uporządkowaniu mają zaowocować konkretną wiedzą. Według francuskiego filozofa jest to niewłaściwa postawa badawcza. Gromadzenie faktów nigdy nie da nam jakiejś ogólnej, obiektywnej teorii, gdyż nie ma czegoś takiego jak

${ }^{2}$ Zwróćmy uwagę, że w pewnych punktach koncepcja Sartre’a zbliżona jest do myśli Levinasa. Obaj filozofowie w swych rozważaniach wychodzą od podobnej intuicji, mianowicie od takiej, że wszelki podmiot jest podmiotem rozdartym. Owo rozdarcie stanowi wynik spotkania z innym, które ma charakter egzystencjalny, ponieważ sam akt spotkania ingeruje we mnie i zmienia moją egzystencję. Jednak w kwestii opisywania procesu, na czym owa „zmiana mnie” polega i jaki wpływ ma ona na mnie, drogi Levinasa i Sartre’a rozchodzą się. W koncepcji Sartre’a zmiana sposobu bycia, jaką pod wpływem spojrzenia inna podmiotowość we mnie wywołuje, polega na tym, że zostaję wyzuty z własnej podmiotowości i staję się przedmiotem. Z kolei u Levinasa spotkanie z drugim sprawia, że odkrywam własną jedyność, wyjątkowość i niezastępowalność. W wyniku zderzenia $\mathbf{z}$ Twarzą czuję się wezwany do podjęcia odpowiedzialności i w ten sposób swoją podmiotowość pogłębiam.

3 J. P. Sartre, Szkic o teorii emocji, tłum. R. Abramciów, Kraków 2006, s. 41. 
„czysty fakt”. Rozumienie zbioru faktów zawsze będzie zależne od wyznawanej przez danego psychologa teorii. Badając w ten sposób człowieka, nie będziemy w stanie poznać istoty człowieczeństwa ${ }^{4}$ I tu rodzi się potrzeba zastosowania metody fenomenologicznej, która bada fenomeny, a nie fakty. Poszukiwania istoty człowieczeństwa, należy zatem łączyć z narzędziami oferowanymi przez fenomenologiczne metody Husserla i Heideggera.

Punktem wyjścia Sartre’owskich rozważań była więc Husserlowska i Heideggerowska fenomenologia. Sartre interpretował jednak naukę niemieckich filozofów w duchu egzystencjalistycznym. Jak wspomniałam, na pierwszym miejscu swoich rozważań stawiał podmiotowość, sposób jej istnienia oraz zagadnienie relacji międzypodmiotowych. Dążąc do rozumienia podmiotu rozwinął aktywistyczne wątki myśli Husserla. Przede wszystkim skupił się na, jego zdaniem, najważniejszej kwestii, a mianowicie na intencjonalności podmiotu, będącej dla niego synonimem aktywności, spontaniczności lub po prostu wolności.

Problem związku jednostkowej podmiotowości z podmiotowością innych ,ja” jest w filozofii Husserla bardzo ważny, lecz zarazem wyjątkowo niejednoznaczny. Z jednej strony w Medytacjach kartezjańskich świadomość zachowuje charakter samotnej monady, konstytuującej świat dzięki własne$\mathrm{mu}$ intencjonalnemu nakierowaniu. Człowiek pojmowany jako monada jest czymś pod każdym względem odrębnym. Znaczy to, że żadne przeżycia przynależące do świadomości jednej monady nie mogą stać się własnością innej. Życie monadyczne może być tu rozpatrywane w różnych aspektach. Może-

\footnotetext{
${ }^{4}$ Warto dodać, że podobną krytykę przeprowadził Heidegger, określając słowa „człowiek”, „świat” mianem pojęć metafizycznych. Zdaniem niemieckiego filozofa, psychologia rości sobie prawo do omawiania tego, co ontyczne (co przeżywa Dasein). Jest to roszczenie bezzasadne, gdyż to, co ontyczne, jest odczuwane bezpośrednio tylko dla bycia tu oto (Dasein) i nie może być dane żadnemu spojrzeniu z zewnątrz (krótko określa to Kierkegaard stwierdzając, że nie można odczuć niczyjego lęku). Psychologia interesuje się sferą tego, co ontologiczne (Seiende). Jest to oczywiście bardzo uproszczony opis tego zagadnienia. Szczegółowe wyjaśnienie Heideggerowskich terminów zob.: M. Żelazny, Filozofia i psychologia egzystencjalna, Wydawnictwo Naukowe UMK, Toruń 2011. Co ciekawe, podobne stanowisko reprezentuje w kwestii filozofii empirycznej i prób definiowania człowieka Levinas, u którego czytamy: „Filozofia intelektualistyczna-empiryczna lub racjonalistyczna dążyła do poznania człowieka, ale zbliżała się do pojęcia człowieka, pomijając faktyczność ludzkiej egzystencji i sens tej faktyczności. Empiryści, choć mówili o ludziach rzeczywistych, również przechodzili obok tej faktyczności, bo intelektualizm może ujmować fakty tylko z zewnątrz, stać „przed” faktami. Brak mu Heideggerowskiego pojęcia egzystencji”. Zob.: E. Levinas, Odkrywając egzystencję z Husserlem $i$ Heideggerem, tłum. E. Sowa, wyd. IFiS PAN, Warszawa 2008, s. 80.
} 
my je odnosić do sfery cielesności, świata, intencjonalnego zwrócenia się ku jakiemuś przedmiotowi, ale można je również ujmować w aspekcie czysto myślowym. Z drugiej strony, w piątej medytacji, Husserl pragnie pokazać, że monadyczność podmiotu jest tylko abstrakcyjnym momentem analizy, gdyż w rzeczywistości istnieje wspólnota monad.

Zagadnieniem relacji ja-inny Husserl zajmował się głównie w późniejszym okresie swojej twórczości. Uznał on wówczas, że podczas spotkania z drugim człowiekiem bardzo ważną funkcję pełni ciało (chodzi mi tu o wprowadzenie rozróżnienia na ciało fizyczne [Körper] i ciało żyjące [Leib]). Według twórcy fenomenologii człowiek jest w stanie dokonać przeniesienia w myśli własnego ciała na miejsce cudzego i w efekcie traktować je tak, jakby sam się $\mathrm{w}$ nim znajdował. Ważnym momentem $\mathrm{w}$ sposobie pojmowania innego jest również uznanie go za podmiot otaczającego mnie świata. Człowiek zawsze jest w jakiś sposób do świata odniesiony, żyje w nim i pozostaje od niego zależny. Inne podmioty świadome są dla nas, by użyć terminologii Leibniza, „monadami bez okien”. Inni, z którymi ja mam do czynienia, tworzą ze mną wspólnotę monad. Wspólnoty tej doznajemy tylko za pośrednictwem relacji czasowo-przestrzennych i dopiero ona umożliwi to, co Jaspers, Heidegger i Sartre nazwą komunikacją egzystencjalną, a właściwie między-egzystencjalną. Owa komunikacja stanowi jedyną gwarancję tego, że świat nie jest dla nas podmiotowym złudzeniem.

Transcendentalną intersubiektywność i jej transcendentalne uwspólnocenie, w którym przy wyjściu od dokonującego systemu biegunów Ja konstytuuje się „świat dla wszystkich” i dla każdego podmiotu, jako świat dla wszystkich, można wykazać metodycznie tylko wychodzące od ego i systematyki jego transcendentalnych funkcji i dokonań. Tylko na tej drodze, w zgodnym $\mathrm{z}$ istotą postępowaniu można dojść do ostatecznego zrozumienia tego, że każde Ja transcendentalne intersubiektywności z konieczności musi być ukonstytuowane jako człowiek w świecie 5 .

Według Husserla świat jest więc o tyle „obiektywny”, o ile istnieje „dla nas”, a nie tylko „dla mnie”. Ten motyw - jak zobaczymy w dalszej części tekstu -

\footnotetext{
${ }^{5}$ Husserliana, tłum. S. Walczewska, s. 190, [w:] K. Święcicka, Husserl, Myśli i ludzie. Wiedza Powszechna, Warszawa 1993, s. 192.

${ }^{6}$ Jest to rozbudowana wersja obiektywności. Na przykład dla Kanta słowo „obiektywny” oznaczało po pierwsze, odnoszą się do przedmiotu (ale takie odniesienie może być dane również w złudzeniu lub marzeniu sennym), po drugie dające się ująć w formę systematyczne-
} 
występuje także w myśli Sartre’a. Drugi podmiot posiada „połowę prawdy” (prawdy zewnętrznej) na temat mojej własnej egzystencji. Dysponuje on częścią prawdy odnoszącej się do świata, który odsłania mu się w pewien sposób z jego własnej perspektywy. Właśnie dlatego dzięki drugiemu człowiekowi ja mogę poznać siebie i otaczającą mnie rzeczywistość.

Sartre stwierdził, że Husserlowi tak naprawdę nie udało się dotrzeć do ważnego wymiaru międzypodmiotowego. Istotny, ale nierozwiązany u Husserla problem relacji ja - inny, zachęcił filozofa do ponownego podjęcia całego tego zagadnienia. Inny nie jest tym, kogo poznaję, ale tym, kto zmienia mój sposób bycia. Spotkanie z innym jest bezpośrednim doświadczeniem samej jego inności poprzez wpływ, jaki wywiera on na moje własne istnienie. Mówiąc kolokwialnie, po spotkaniu z innym nie jestem ,już taki sam jak kiedyś’. Sartre dostrzegł niewystarczalność Husserlowskich prób opisania relacji międzypodmiotowych w języku konstytucji innych podmiotów przez monadyczne „ja”. W sposobie myślenia Husserla widział zagrożenie solipsyzmem, groźbę uznania innych podmiotów tylko za zjawiska dla „ja”. Zgodził się jednak z Husserlem, że inny podmiot właśnie dlatego, że jest inny, jest dostępny dla ,ja” w sposób zasadniczo odmienny od tego, w jaki jest on dostępny sam dla siebie.

Pierwsze zadanie, jakie stawia sobie w tym miejscu Sartre, to uchwycenie momentu wyłaniania się ludzkiej podmiotowości. Różnica między bytem a byciem to dla Sartréa mniej więcej to samo, co różnica między jednostkowością a ogólnością. W stosunku do bytu, nazwijmy go „szczegółowego”, bycie jako takie jest czymś ogólnym i wspólnym. Francuski filozof próbuje przedstawić sposób zerwania $z$ byciem jako takim, a owo zerwanie jest równoznaczne z wyłonieniem się podmiotowości rozumianej jako tożsamość lub indywidualność. Nie chodzi tu bynajmniej o chęć odnalezienia alternatywy

go związku przy użyciu kategorii intelektu. Kant chyba nie byłby przekonany co do tego, że gwarantem prawdziwości może być komunikacja egzystencjalna sama w sobie. Stwierdziłby, że komunikacja taka możliwa jest również we śnie. Komunikacja taka być może musi pozostawać jeszcze w zgodzie z systematycznym związkiem kategorii i intelektu. Powołując się na Arystotelesa (faktycznie chodziło o Heraklita) pisał on: „Gdy czuwamy, mamy świat wspólny, gdy śnimy, każdy ma swój świat”. (I. Kant, Marzenia jasnowidzącego objaśnione przez marzenia metafizyki, tłum. M. W. Kozłowski, [w:] I. Kant, Dzieła zebrane, t. 1, s. 773). Jaspers, Heidegger i Sartre myśleli podobnie. Może być przecież złudzenie systematycznego związku obiektów, a także złudzenie komunikacji egzystencjalnej, ale nie może być złudzenia dwupiętrowego: że coś łączy się w systematycznym związku logicznym z wszystkim innym, oraz że istnienie takiego związku stwierdzam nie tylko ja sam, lecz również potwierdzają go inni. Husserl myślał podobnie i Sartre chyba nie do końca go zrozumiał. 
wobec bycia jako takiego, bo takowa oczywiście nie istnieje, ale o wyłom, czy może raczej pewnego rodzaju pęknięcie, spowodowanie jego rozdarcia ${ }^{7}$.

Dla Sartre’a byt to pojęcie absolutnie pierwotne. Jest on tym, czym jest, stwierdza trywialnie filozof. Byt (être) nie jest stworzony ani tworzący się. Nie jest również konieczny. Po prostu jest i to jego istnienie (existence) właściwie nic nam nie tłumaczy. W efekcie według francuskiego filozofa byt jest czymś bezzasadnym, a co za tym idzie, absurdalnym. Owego nieusuwalnego, niewytłumaczalnego bytu doświadczamy poprzez mdłości. Z jednej strony, byt jest czymś najbardziej intymnym, ponieważ stanowi podstawę istnienia, a z drugiej, czymś obcym i przytłaczającym. Dlatego według Sartre’a człowiek uwikłany jest w paradoks: podmiotowość możliwa jest na gruncie bytu, ale równocześnie powoduje jego negację w sensie „transcendowania ku”.

Istotę mdłości (nausée) Sartre przedstawił w swojej powieści Mdłości. Bohater tej książki Antoine Roquentin to samotnik, który przyjeżdża do miasta Bouville, gdzie zaczyna pisać dziennik. Główną postacią tegoż dziennika jest markiz de Rollebon. W pewnym momencie Roquetin zdaje sobie sprawę, że nie jest w stanie opisać czegoś, co należy do przeszłości, w związku z czym zaczyna notować swoje przemyślenia, obserwacje i wydarzenia $\mathrm{z}$ własnego życia. Pisarz dostrzega nieautentyczność ludzkiego życia. Nad ludzką egzystencją ciąży poczucie absurdalności i przypadkowości.

Więc to są Mdłości: ta oślepiająca oczywistość? [...] Ja istnieję - świat istnieje. I ja wiem, że świat istnieje. To wszystko.

Odnalazłem klucz do Istnienia, klucz do moich Mdłości, do mego własnego życia. Rzeczywiście, wszystko, co mogłem później uchwycić, sprowadza się do tej podstawowej absurdalności ${ }^{8}$.

Owo poczucie tragizmu istnienia ludzie próbują w sobie zagłuszyć poprzez istnienie nieautentyczne, czyli nadawanie swemu życiu jakiejś wartości pozornej.

${ }^{7}$ Zagadnienie bytu rozdartego opisuje Małgorzata Kowalska w swojej książce Dialektyka poza dialektyką. Wedle autorki teza mówiąca o tym, że podmiot jest podmiotem rozdartym ma w historii filozofii długą tradycję. Różne jej wersje znajdujemy choćby u Pascala, Hegla czy Lacana, a samo pojęcie rozdarcia można rozumieć na różne sposoby. Kowalska zwraca uwagę na to, że interesujące ją pojęcie może mieć charakter separacji, negacji, może także przebiegać na różnych polach, na przykład ontologii czy etyki. Zob. M. Kowalska, Dialektyka poza dialektyką. Od Bataille’a do Derridy, Fundacja Aletheia, Warszawa 2000.

${ }^{8}$ J. P. Sartre, Mdłości, tłum. J. Trznadel, Wyd. Zielona Sowa, Kraków 2005, s. 174-182. 
Wszystko, co działo się wokół nich, zaczęło się i skończyło poza polem ich widzenia; długie ciemne formy, wypadki, które przychodziły z daleka, otarły się o nich w pędzie i kiedy chcieli na nie spojrzeć, było już po wszystkim. A potem koło czterdziestki ochrzcili swoje małe upory i kilka przysłów mianem doświadczenia. [...] chcieliby nam wmówić, że ich przeszłość nie jest przegrana, że ich wspomnienia skondensowały się, miękko przekształcone w mądrość 9 .

W takiej formie główny bohater powieści notuje swe spostrzeżenia na temat farsy, jaką ludzie odgrywają po to, aby zapomnieć o absurdalności własnego życia. Tytułowe mdłości wynikają stąd, że po prostu jestem i nic nie mogę na to poradzić ${ }^{10}$.

Zagadnienie mdłości łączy się z pojęciem wstydu, który pojawia się, gdy uświadomimy sobie własną cielesność.

Wstydzę się tego, czym jestem. Wstyd potwierdza zatem głęboką, wewnętrzną relację między mną i moim ,ja”: poprzez wstyd odkryłem pewien aspekt mojego bytu. [...] otóż przed chwilą wykonałem jakiś niestosowny bądź wulgarny gest; ów gest niejako przykleja się do mnie, zespala ze mną: nie oceniam go ani nie potępiam, lecz po prostu nim żyję, urzeczywistniam go na sposób bytu-dla-siebie.

Pisze Sartre w Bycie i nicości ${ }^{11}$.

Wstydzimy się naszej egzystencji, której nie jesteśmy w stanie ukryć nawet przed sobą. Sam byt odkrywamy zarówno we wstydzie, jak i w nudnościach. Stan nudności ogarnia nas niejako od wewnątrz. Dławimy się sami sobą i nie możemy się od tego uwolnić. Należy jednak podkreślić, co będzie niezwykle

\footnotetext{
${ }^{9}$ J. P. Sartre, Mdłości, s. 109-110.

${ }^{10}$ Bardzo podobne analizy znajdujemy u Levinasa. Przede wszystkim mam tu na myśli treść wczesnego artykułu francuskiego myśliciela O uciekaniu (De l’evasion). Dzieło i zawarte w nim wnioski są bardzo podobne do Sartre’owskich Mdłości. „W mdłościach tkwi pewnego rodzaju odmowa przebywania w tym stanie, wysiłek, aby się z niego wydostać. Wysiłek ten jest jednak natychmiast uznany za beznadziejny, w każdym razie wobec jakiejkolwiek próby działania lub myślenia. Beznadziejność ta, fakt bycia przykutym do siebie leżą u podstaw lęku, jaki wywołują mdłości. W mdłościach, które są wszak niemożnością bycia tym, czym się jest, jednocześnie jest się do samego siebie przykutym [...] właśnie to jest doświadczeniem czystego bycia”. Czytamy w O uciekaniu. Zob.: E. Levinas, O uciekaniu, tłum. A. Czarnacka, Wyd. IFiS PAN, Warszawa 2007, s. 30. La Nausée ukazały się w 1938 roku, czyli trzy lata po opublikowaniu De l’evasion. Nie wiemy jednak czy Sartre, pisząc Mdłości, inspirował się owocem pracy Levinasa.

${ }^{11}$ J. P. Sartre, Byt i nicość. Zarys ontologii fenomenologicznej, tłum. zbiorowe, Wyd. Zielona Sowa, Kraków 2007, s. 287.
} 
istotne w kontekście moich dalszych rozważań, że Sartre’owski wstyd łączy się z obecnością innego człowieka, który na mnie patrzy. W dalszej części wcześniej zacytowanego przeze mnie fragmentu Bytu i nicości czytamy:

Ale oto teraz podnoszę głowę i spostrzegam, że ktoś tu był i mnie widział. Natychmiast uświadamiam sobie całą wulgarność mojego gestu i jestem zawstydzony [...] wstydzę się siebie takiego, jakim ukazuję się innemu ${ }^{12}$.

Sartre rozszerza pojęcie wstydu (jego doznawania) na zjawiska pochodzące ze świata zewnętrznego. Wstyd okazuje się reakcją na spotkanie z innym.

Dla Sartre’a bycie w ogóle jest niejako fundamentem bytów jednostkowych. Francuski filozof oprze swoje rozważania na dwóch głównych pojęciach o proweniencji Heglowskiej: bytu-w-sobie oraz bytu-dla-siebie. W jego koncepcji na bazie bytu-w-sobie tworzy się byt-dla-siebie. Podmiotowość nie jest niczym innym aniżeli świadomością dokonującą negacji bytu w sobie.

Przyjrzyjmy się bliżej podstawowym pojęciom Sartre’owskiej filozofii. Są to oczywiście kategorie bytu (être) i nicości (néant). Sposób rozumienia obu wartości Sartre przejmuje od Hegla. Nicością jest wszystko to, co było, bo już nie jest oraz to, co będzie, bo jeszcze tego nie ma. To, co było i to, co będzie możemy przywołać do istnienia albo poprzez naszą pamięć, albo dzięki naszej wyobraźni. Zatem nie istnieje coś tu i teraz jako punkt czasowy. Rzeczywistość jest albo przeszłością, albo przyszłością, czyli po prostu nicością. Takie rozumienie świata zmysłowego wiąże się z przejętą od Husserla koncepcją czasu. Dla niemieckiego filozofa teraźniejszość pojmowana jest jako plama trwania. Nie ma jakiegoś oderwanego punktu jako tu i teraz. Będąc w świecie, czyli w pozycji ,jest” ja nieustannie powołuję do istnienia coś, co samo w sobie nie jest, czyli nicuję świat, w którym żyję. Rdzeniem mego bycia tu oto (Sartre używa Heideggerowskiego terminu Dasein zamiennie z terminem ludzka rzeczywistość [réalité humaine]) jest byt-sam-w-sobie (lêttre-ensoi) pojmowany jako trwanie w ogóle (podobne znaczenie ma il y a wprowadzone przez Levinasa). Treścią tego mojego bycia oto (Dasein) są wszystkie wartości, zjawiska itp. płynące ze świata. I tu pojawia się druga obok bytu-w-sobie ważna kategoria, a mianowicie byt-dla-siebie (lêtre-pour-soi).

12 Tamże, s. 288. 
Byt-dla-siebie nie jest bytem-w-sobie i nie mógłby nim być; wszak jest jedynie możliwą, relacją do bycia-w-sobie; jest on nawet jedyną możliwą relacją do bycia-w-sobie, jako że z każdej strony toczony jest bytem-w-sobie. Wymyka mu się jedynie dlatego, że jest niczym i nic go od niego nie oddziela. Byt-dla-siebie jest fundamentem każdej negatywności i każdej relacji, on jest relacją ${ }^{13}$.

Byt-w-sobie po prostu jest. Stanowi niejako podstawę tego, by coś mogło zaistnieć jako byt-dla-mnie. Byt-w-sobie uobecnia się tylko w procesie nadawania istnienia jakiemuś bytowi-dla-siebie. Nie jest możliwe odizolowanie bytu-w-sobie od bytu-dla-siebie. Nie znajdę bytu-w-sobie w czystej postaci, bo nie mogę samego siebie odizolować od świata, w którym żyję. Byt-w-sobie zawsze będzie przesłonięty bytem-dla-siebie, czyli wszystkimi doświadczeniami płynącymi z zewnątrz. Moje życie polega na nieustannej ucieczce od bytu-w-sobie w formy bytu-dla-siebie, ale obie formy bytu mogą istnieć tylko we wzajemnym związku.

Byt-dla-siebie jako nicościowanie bytu-w-sobie objawia się w czasie jako ucieczka ku [fuite vers]. Przekracza on w istocie swą faktyczność - czy to jako byt dany, czy przeszły, czy też ciało - w kierunku bytu-w-sobie, którym byłby, gdyby mógł być swoim własnym fundamentem ${ }^{14}$.

Owa nicująca ucieczka została przez Sartre’a określona mianem transcendowania. Człowiek nieustannie ucieka: albo poprzez wspominanie czegoś, co już było, albo poprzez wyobrażanie sobie czegoś, co dopiero nastąpi. Transcendując, człowiek wykracza z bytu w nicość. Owo wykraczanie jest projektowaniem zbioru cech, wartości, które tworzą jego rzeczywistość i jego samego, czyli po prostu esencję. Można powiedzieć, że byt-w-sobie jest egzystencją/ ludzką rzeczywistością, a byt-dla-siebie esencją/oczekiwaną sytuacją w świecie, natomiast związek obu form ma charakter dialektyczny. Związek między bytem-w-sobie a bytem-dla-siebie dokonuje się poprzez wspomniane transcendowanie. Mogę transcendować do przodu, poprzez oczekiwanie na coś lub wyobrażanie sobie czegoś. Nie jestem jednak w stanie przewidzieć przyszłości, co napawa mnie egzystencjalnym lękiem. Ja tu i teraz, byt-w-sobie wyobrażam sobie siebie jako tego, którym jeszcze nie jestem. W miejsce owego oczekiwania tego, jakim będę, wślizguje się nicość, która objawi się we właściwym czasie.

\footnotetext{
13 Tamże, s. 452.

${ }^{14}$ Tamże, s. 451-452.
} 
Przykładowo: jestem umówiona na kawę z koleżanką. Oczekuję że znajoma przyjdzie na spotkanie. Mój byt-w-sobie transcenduje w stronę wyobrażenia, jakim jest owa „kawa z koleżanką”. Ale koleżanka nie przychodzi. W miejsce mojego oczekiwania wślizguje się nicość, czyli coś, czego się nie spodziewałam (taki sam proces przebiega $\mathrm{w}$ przypadku transcendowania $\mathrm{w}$ przeszłość). Umiejętność transcendowania wyznacza istotę bycia człowiekiem. Tożsamość „ja” powstaje każdorazowo w aktach świadomości. Nie ma czegoś takiego jak kartezjańskie ja budowane poza światem i względem świata autonomiczne.

Bez świata nie ma sobości [ipséité], nie ma nikogo; bez sobości, bez nikogo nie ma świata. Lecz ta przynależność świata do kogoś nie jest nigdy ustanawiana na płaszczyźnie przedrefleksyjnego cogito. Byłoby absurdem powiedzieć, że świat taki, jakim go znamy, jest znany jako mój. A jednocześnie ta „mojość” $[<<$ moiité $>>]$ jest strukturą nietrwałą i zawsze obecną, gdy żyję. Świat (jest) moim, bo jest nawiedzany przez możliwości, które są świadomościami możliwych świadomości sobości [(de) soi] którą jestem, i są to możliwości jako takie, które ofiarowują sobości swą jedność i swój sens świata ${ }^{15}$.

Kategoria sobości (ipséité) oznacza identyczność mnie z samym sobą $\mathrm{w}$ horyzoncie zmian czasowych. Obejmuje również problem relacji wszystkiego, co dla mnie może być bytem dla siebie. Dla Sartre’a istotne jest, że człowiek żyje w ogóle w świecie. Wartości pochodzące ze świata wpływają na człowieka, ale również człowiek ma wpływ na postrzeganie świata. Zachodzi silny związek między światem a żyjącym w nim człowiekiem. U Sartre’a człowiek jest od razu niejako „wrzucony w świat”. Owo życie w świecie, wpływ zjawisk zewnętrznych na człowieka oraz wpływ człowieka na świat, widzimy na przykładzie rodzenia się emocji. „Ja” (jako Dasein) pojmuję świat poprzez swoje bycie w nim, konkretnie poprzez działanie. Jeśli jestem szczęśliwy, to moje szczęście jest sposobem, w jaki ów świat mi się objawia. Podobnie, jeśli w danej chwili się irytuję, moja irytacja jest sposobem pojmowania świata w określonym „momencie”, czyli „wycinku” rzeczywistości, który jawi mi się jako irytujący.

Podmiot, który szuka rozwiązania problemu praktycznego, znajduje się w świecie na zewnątrz, pojmuje świat w każdej chwili, poprzez każdy swój czyn [...] I nie ma takiej konieczności, żeby podmiot, pomiędzy działaniem, które mu się

15 Tamże, s. 152. 
nie udaje, a gniewem, powracał do siebie i wstawiał pomiędzy nie świadomość refleksyjną ${ }^{16}$.

Sądzę, że w tym punkcie koncepcja Sartre’a jest bardzo zbliżona do tego, o czym pisze Heidegger. Przypomnijmy pokrótce: moje bycie tu oto (Dasein) otwiera się w bezpośredni sposób na swoje bycie (Sein), czyli egzystencję. $D a$ sein bezpośrednio odczuwa to, jakie jest. Główna teza filozofii niemieckiego myśliciela brzmi: moje bycie tu oto (Dasein) otwiera sobą świat. Wszystko, czego doświadczam i co odczuwam w świecie, jest doświadczane i odczuwane przez pryzmat mojego aktualnego bycia tu i teraz. Na przykład: jeśli jestem nieszczęśliwy, otwieram sobą świat pełen smutku. Otwierając zaś ów świat, nadaję mu pewne bycie, jako czemuś będącemu (Seiende), a nadaję mu je poprzez pryzmat tego, jaki sam jestem w danej chwilii ${ }^{17}$.

Na przykładzie koncepcji emocji przedstawionej we wczesnej rozprawie Szkic o teorii emocji, można stwierdzić, że Sartre’owska podmiotowość ma charakter otwarty. Sartre zaznacza, że podmiot istnieje w świecie, czyli w sytuacjach. Podmiot zmienia się pod wpływem zjawisk pochodzących z zewnątrz, ale także świat, a raczej wycinki rzeczywistości, zmieniają się pod wpływem działania podmiotu. Poprzez intencjonalność podmiot łączy się ze wszystkimi zjawiskami płynącymi ze świata.

Ostatecznie wszystko jest na zewnątrz, wszystko łącznie z nami samymi; na zewnątrz, w świecie, pośród innych. Odkrywamy siebie nie w jakimś ustroniu, ale na drodze, w mieście, w tłumie, jako rzecz pośród rzeczy, człowieka wśród innych ludzi ${ }^{18}$.

Takie pojmowanie podmiotu w świecie ściśle łączy się z opisanym przeze mnie transcendowaniem ku.

Jak pamiętamy z wcześniejszych rozważań Sartre’a, wprowadza on do swojej koncepcji kategorię „sobości”, która wiąże się z zagadnieniem wzajemnej relacji tego wszystkiego, co może stanowić mój byt-dla-siebie. Stosunek

\footnotetext{
16 J. P. Sartre, Szkic, o teorii emocji, s. 69.

${ }^{17}$ Wzorce zachowania charakteryzujące to, jak ja jestem w świecie, Heidegger nazywa egzystencjałami. Natomiast określenia bycia czegoś będącego (ale nie Dasein) to kategorie. W swoim dziele Bycie i czas, niemiecki filozof omawia znaczenie poszczególnych egzystencjałów. Najważniejsze z nich to: egzystencjał bycia w; zatroskanie, mowa, byt ku śmierci, światowość, bycie przy.

${ }^{18}$ J. P. Sartre, Intencjonalność jako kategoria egzystencjalna, tłum. A. Milecki, [w:] Filozofia egzystencjalna, red. L. Kołakowski, K. Pomian, PWN, Warszawa 1965, s. 11.
} 
człowieka do przedmiotów może przyjąć formę złej wiary (la mauvaise foi), ale nie jest ona niczym szkodliwym. Nie należy jej także utożsamiać z kłamstwem.

Zła wiara nie zachowuje norm i kryteriów prawdy, przyjmowanych przez myśl krytyczną inspirowaną dobrą wiarą ${ }^{19}$.

Według Sartre’a nie należy jednak, opierając się złej wierze, budować jakichkolwiek relacji międzyludzkich. Aby w ogóle mogła zostać nawiązana relacja, niezbędne jest, ażeby chociaż w pewnym stopniu przebiegała ona w sferze dobrej wiary, którą można poddać weryfikacji.

Jeśli człowiek jest tym, czym jest, zła wiara jest raz na zawsze niemożliwa, a szczerość przestaje być dla niego ideałem ${ }^{20}$.

Na podstawie złej wiary nie można budować moralności, ale warto również podkreślić, że jej pozamoralny sens nie oznacza, że ma ona prowadzić do zachowania niemoralnego. Jak wyjaśnia Żelazny:

Złą wiarę objawiali na przykład dostojnicy, którzy wprowadzali dzieło De Revolutionibus Kopernika na indeks kościelny, choć nawet nie byli w stanie ocenić wagi użytych przez wielkiego astronoma argumentów. Gdy idzie o relacje w związkach międzyludzkich, zła wiara poprzez swój możliwy nieetyczny sens staje się zjawiskiem o wiele bardziej skomplikowanym ${ }^{21}$.

Przypomnijmy pokrótce, że sprowadzenie jakiegoś wydarzenia do mojego bytu-w-sobie polega na każdorazowym „oswajaniu” owego bytu. Przykładowo: kiedy wyobrażam sobie jakieś wydarzenie znaczy to, że transcenduję w przyszłość. Oczekuję pewnego zdarzenia, ale ono nie następuje ${ }^{22}$ (czyli byt nie przychodzi na spotkanie). Tu, jak pisze Sartre, dochodzi do wślizgnięcia się nicości, bo zamiast zdarzenia oczekiwanego, nadchodzi inne. W konsekwencji obcość tego nowego wydarzenia staram się przetworzyć jakiś byt-dla-siebie po to, aby przestało być obce i zaczęło tworzyć moją sobość. $\mathrm{W}$ koncepcji Sartréa spotkanie $\mathrm{z}$ innym również prowadzi do naruszenia mojej integralności. Ale próba nawiązania kontaktu $\mathrm{z}$ drugim rodzi wiele różnorakich problemów. Inny przejawia więc własną, autonomiczną postawę, przez co nie mogę z niego uczynić jakiegoś bytu-dla-mnie, jak w przy-

\footnotetext{
19 Tamże, s. 329.

${ }^{20}$ Tamże, s. 97.

${ }^{21}$ M. Żelazny, Filozofia i psychologia egzystencjalna, Wyd. Naukowe UMK, Toruń 2011, s. 339.

${ }^{22}$ Sartre stwierdza wtedy, że „byt nie przychodzi na spotkanie”. Takie samo znaczenie ma stwierdzenie użyte przez Heideggera „byt się uchyla”.
} 
padku przedmiotów. Stawia on też opór wszystkim moim wyobrażeniom o nim, a głównym problemem staje się nie zagadnienie tego, kim inny dla mnie jest, ale to, kim bądź czym ja jestem dla innego.

Jestem doświadczeniem innego, oto fakt źródłowy

- stwierdza Sartre ${ }^{23}$.

W koncepcji Sartre’a doświadczam innego poprzez spojrzenie, jakim inny mnie obdarza.

Inny mnie posiada; spojrzenie innego kształtuje moje ciało w jego nagości, sprawia, że ono się rodzi; rzeźbi je, wytwarza je takim, jakie jest, widzi je tak, jak ja nigdy go nie zobaczę. Inny przechowuje sekret - sekret tego, czym jestem. Sprawia, że jestem i już przez to posiada mnie, a posiadanie to nie jest niczym innym, jak świadomością posiadania mnie. Ja zaś, uznając swą przedmiotowość, doświadczam tego, że on tę świadomość ma ${ }^{24}$.

Spojrzenie innego nigdy nie będzie należało do mnie. To, jak widzi mnie inny, zawsze będzie stanowiło pewnego rodzaju esencję mnie, która jednak nigdy nie będzie należała do mojej sobości. Nie pragnę bynajmniej, ażeby inny przestał być innym. Chcę tylko wiedzieć, co kryje się za jego spojrzeniem skierowanym w moją stronę.

Mój byt jako przedmiot jest przypadkowością nie do zniesienia i czystym posiadaniem mnie przez innego [...] chodzi mi w istocie o ustanowienie mojego bytu poprzez uzyskanie punktu widzenia innego ${ }^{25}$.

W przypadku Sartre'a to inny, patrząc na mnie, wytycza granice mojej wolności, co więcej, chce on nade mną panować. Aby się przed owym panowaniem zabezpieczyć, ja tworzę sobie wizerunek siebie jako osoby w świecie, ale takie samo zabezpieczenie inny tworzy względem mnie. Nie chcę być w oczach innego przedmiotem, inny również nie chce być postrzegany jako przedmiot. Obaj próbujemy uciec od siebie nawzajem, ale nie jest to możliwe. Jedyne co możemy uczynić to uzyskać wzajemną niezależność.

Wszystko, co dotyczy mnie, dotyczy innego. Podczas gdy ja próbuję uwolnić się od panowania innego, inny próbuje uwolnić się od mojego panowania.

\footnotetext{
${ }^{23}$ J. P. Sartre, Byt i nicość, s. 453.

${ }^{24}$ Tamże, s. 454.

25 Tamże, s. 455.
} 
Podczas gdy staram się ujarzmić innego, inny stara się ujarzmić mnie. Nie chodzi tu wcale o relacje jednostronne z przedmiotem-w-sobie, ale o stosunki wzajemne i zmienne. Dalsze opisy muszą więc być rozpatrywane z perspektywy konfliktu. Konflikt jest sensem pierwotnym bytu-dla-innego ${ }^{26}$.

Ową sytuację ilustruje poniższy schemat:

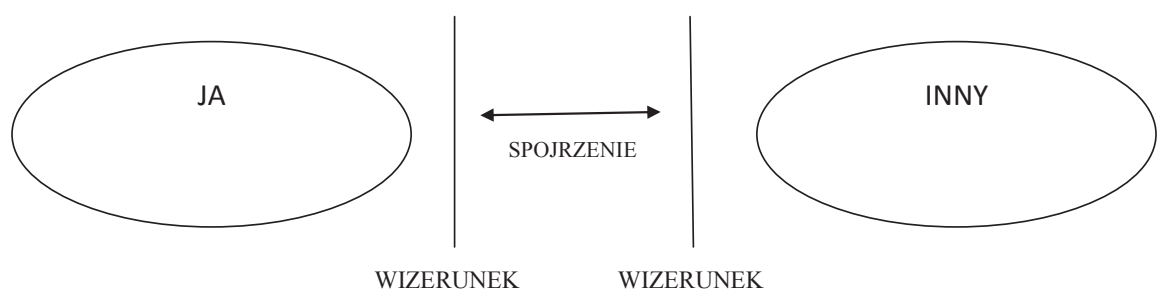

Aby uchronić się od spojrzenia innego, kreuję nowego siebie (często jest to kreacja pełna złej wiary), a tym samym ukrywam swoje prawdziwe ,ja”. Używając terminologii Levinasa: przesłaniam Twarz ${ }^{27}$.

Sytuacja, w której inny jakoś nas postrzega, ale my tak naprawdę nie wiemy jak, jest dla nas bardzo niekomfortowa. Szczególnie silnie odczuwamy to w sferze cielesnej ${ }^{28}$.

W swym dziele Byt i nicość francuski filozof wyróżnia trzy podstawowe zasady postawy wobec innego są to: 1) miłość, język i masochizm; 2) obojętność, pożądanie, nienawiść i sadyzm; 3) „bycie-wespół-z. W niniejszym tekście chciałabym scharakteryzować relacje miłości, sadyzmu, masochizmu oraz współbycia-oto. Francuski myśliciel wyjaśnia, że:

Miłość jako pierwotny stosunek do innego, jest zbiorem projektów, przez które zmierzam do urzeczywistnienia tej wartości. Projekty te wprowadzają mnie w bezpośredni kontakt $\mathrm{z}$ wolnością innego. $\mathrm{W}$ tym właśnie znaczeniu miłość jest konfliktem ${ }^{29}$.

\footnotetext{
26 Tamże, s. 454.

${ }^{27}$ Pisze o tym inspirowany myślą Levinasa Józef Tischner w swej książce Filozofia drama$t u$. Tischner przedstawia zagadnienia typu: „zasłonięcie Twarzy” (związane ze wstydem) oraz „nałożenie na Twarz maski” (związane z kłamstwem). Zob. J. Tischner, Filozofia dramatu, Znak, Kraków 2006, s. 52-62.

${ }^{28}$ Mirosław Żelazny bardzo słusznie zauważa, że ową mękę bardzo silnie przeżywamy w sferze życia erotycznego. Zob. M. Żelazny, Filozofia i psychologia egzystencjalna, s. 340-346.

${ }^{29}$ J. P. Sartre, Byt i nicość, s. 456.
} 
Obdarzając kogoś miłością, często dążymy do tego, aby inny jednocześnie oddał nam swoją wolność (chcemy, by był tylko dla nas), a $\mathrm{z}$ drugiej strony nie chcemy również, aby kochał nas z przymusu i pragniemy, żeby ową wolność mógł zachować. Dlatego według Sartre’a miłość jest utożsamiana $\mathrm{z}$ konfliktem.

Kochający chce być dla kochanego „wszystkim na świecie”. Oznacza to, że ustawia się on po stronie świata; jest tym, co streszcza i symbolizuje świat ${ }^{30}$.

Najważniejszą rzeczą dla kochającego jest pozyskanie możliwie największej uwagi przez kochanego. Chcemy być dla ukochanego najważniejszą osobą na świecie. Ale całkowite odebranie innemu jego wolności, przekreśla możliwość istnienia miłości. Nie chcemy kochającej osoby ujarzmiać, kochając szczerze, pragniemy, aby osoba ta, patrząc na nas, zupełnie bezinteresownie i dobrowolnie równocześnie przeżywała szczęście.

W ten sposób chcieć być kochanym, to zarażać innego swoją własną faktycznością, to chcieć zmuszać go do ciągłego stwarzania nas od nowa jako warunek wolności, która się podporządkowuje i która się angażuje; to chcieć jednocześnie, żeby wolność ustanawiała fakt i żeby fakt miał wyższość nad wolnością ${ }^{31}$.

Z miłością wiąże się nieustanny lęk. Chcemy wiedzieć, co myśli o nas druga osoba, a jednak nie jesteśmy w stanie odgadnąć co kryje się za jej spojrzeniem. Dla owego spojrzenia próbujemy stać się zatem idealnym obiektem, czyli zmieniamy nasze nawyki, zainteresowania itp. Aby zachować miłość innego, rezygnujemy z tego, co kiedyś sprawiało nam radość. Taką postawę Sartre nazywa masochizmem oraz sadyzmem.

Istota masochizmu polega na tym, że ja próbuję odgadnąć, czego oczekuje ode mnie partner i chcę się tym oczekiwaniom podporządkować. Ograniczam zatem swoją wolność, a swoje istnienie sprowadzam do bycia przedmiotem. Tu rodzi się jednak kolejny problem. Próbuję podporządkować się logice spojrzenia innego, ale nigdy nie będę w stanie tego zrobić, ponieważ drugi-sadysta takowej logiki nie posiada. W tak opisanej sytuacji ja reprezentuje postawę masochistyczną: całkowicie poświęca się innemu.

Levinas również pisze o poświęceniu się innemu, ale w jego przypadku owo poświęcenie się pogłębia moją podmiotowość i wyjątkowość. Levina-

\footnotetext{
${ }^{30}$ Tamże, s. 458.

${ }^{31}$ Tamże, s. 459.
} 
sowskie poświęcenie, mówiąc kolokwialnie, jest dla mnie po prostu czymś dobrym. W koncepcji Sartre’a natomiast, poświęcając się sadyście, równocześnie pozwalam się uprzedmiotowić.

Zamiast projektować wchłanianie innego, przy zachowaniu jego odmienności, będę projektował wchłonięcie mnie przez innego i zatracenie w jego subiektywności po to, by pobyć się subiektywności własnej. Przedsięwzięcie przełoży się na konkretną płaszczyznę w postawie masochistycznej. [...] Tutaj moja własna subiektywność rozważana jest jako przeszkoda w zasadniczym akcie, poprzez który inny mógłby mnie ustanowić w moim byciu. Ją należy przede wszystkim negować moja własna wolność. Próbuję więc wciągnąć się całkowicie w mój byt-jako-przedmiot, odmawiam, odmawiam bycia niczym więcej ponad bycie przedmiotem, spoczywam w nim ${ }^{32}$.

Należy jeszcze zaznaczyć, że oddanie i uległość masochisty często rodzi w sadyście irytację. Zatem osoba o charakterze masochistycznym nigdy nie zrealizuje oczekiwań względem swego partnera.

Masochista na próżno upada na kolana, przyjmuje śmieszne postawy, daje się używać jako proste, nieożywione narzędzie, to dla innego będzie on obsceniczny czy po prostu bierny, to dla innego będzie te postawy znosit ${ }^{33}$.

Relacja masochisty z sadystą opiera się na wzajemnej walce. Tego typu związki prędzej czy później się rozpadają. Jak wyjaśnia Żelazny, masochista i sadysta: „sprawiając sobie ból nie mogą żyć bez siebie, nawzajem nad sobą panują i nawzajem są swymi niewolnikami. A jest to układ chory" ${ }^{34}$.

Związek masochisty z sadystą jest przykładem miłości niewłaściwej. Miłość właściwa według francuskiego filozofa polega na budowania wspólnej sfery „my” (Heideggerowskie mit-dasein, czyli współbycie tu oto). Sfera ta zawiera w sobie coś, co jest wspólne dla ,ja” i „ty”, czyli wspólne zainteresowania lub obowiązki oraz to, co z „ja” nie należy do „ty”, na przykład jakieś marzenie „ja”, oraz to, co z „ty” nie należy do „ja”, na przykład realizacja jakiegoś celu.

Pewne sytuacje wydają się bardziej odpowiednie, aby się powiodło doświadczenie „my”. W szczególności wspólna praca: w czasie, gdy wiele osób doświadcza

\footnotetext{
${ }^{32}$ Tamże, s. 469.

${ }^{33}$ Tamże, s. 469.

${ }^{34}$ M. Żelazny, Filozofia i psychologia egzystencjalna, s. 349. Istotę relacji masochistycznej autor wyjaśnia na przykładzie filmu Andrzeja Wajdy Dyrygent.
} 
siebie jako uchwyconych przez trzeciego podczas zgodnego tworzenia tego samego przedmiotu ${ }^{35}$.

Chodzi więc o relację bycia ze sobą przy równoczesnym zachowaniu w stosunku do siebie szerokiej autonomii. Przykładem takiej relacji może być związek Sartre’a z Simone de Beauvoir. Ich relacja w ogromnej mierze opierała się na wspólnej pracy i zainteresowaniach. Nigdy nie wzięli jednak ślubu, co więcej nigdy nie mieszkali ze sobą, a ich związek dzisiaj można byłoby określić jako „Związek otwarty”36.

Kolejną opisywaną przez Sartre’a relacją jest pożądanie seksualne. Rodzi się ono, gdy innego zapragnę fizycznie. Jest ono pragnieniem pierwotnym, ponieważ pierwszy bodziec mogący je zrodzić znajduje się już w akcie wyjaśnionego przeze mnie kilka stron wcześniej spojrzenia. Takim bodźcem jest oczywiście ciało innego. Sartre zauważa jednak, że pociąg seksualny, który może zostać zwieńczony stosunkiem seksualnym, jest tylko pierwszą fazą pragnienia bycia $z$ innym. Sam akt jest czymś pierwotnymi i chwilowym, natomiast pożądać możemy osoby, która na pierwszy rzut oka nawet nam się fizycznie nie podobała.

Żadnej teorii subiektywistycznej ani immanentystycznej nie udadzą się wyjaśnienia, że pożądamy pewnej kobiety, a nie tylko zwyczajnie własnego zaspokojenia ${ }^{37}$.

Związane $\mathrm{z}$ ciałem fizyczne pożądanie zawsze jednak wiąże się z poważnym problemem: otóż nie jesteśmy w stanie posiąść ciała innego na stałe. Może nam się tylko wydawać, że inny ofiarowuje nam swoje ciało. To zagadnienie Sartre opisuje jako „bezwstyd”.

Bezwstyd pojawia się w chwili, gdy ciało przybiera postawy, które odzierają je całkowicie z działania i odkrywają bezwład jego cielesności ${ }^{38}$.

\footnotetext{
${ }^{35}$ J. P. Sartre, Byt i nicość, s. 515.

${ }^{36}$ Związek Sartre’a z Beauvoir w ciekawy sposób opisuje Hazel Rowley, w swojej książce Tête à tête. (zob. H. Rowley, Tête à Tête. Opowieść o Simone de Beauvoir i Jean-Paulu Sartrze, tłum. J. Kalińska, Wyd. Jacek Santorski, Warszawa 2006.

${ }^{37}$ J. P. Sartre, Byt i nicość, s. 477.

${ }^{38}$ Tamże, s. 496.
} 
Ku takiemu ciału (na przykład ciału pokazanemu w filmie pornograficznym) nie możemy transcendować. Obiektem transcendowania mogą być tylko ciała pozbawione cielesności, czyli na przykład takie, które ukazane są na fotografii artystycznej.

Ciało najbardziej obdarzone wdziękiem to ciało nagie, otoczone niewidzialnym płaszczem jego działań, które zasłaniają całkowicie jego cielesność, mimo że cielesność jest całkowicie obecna dla oczu oglądających. ${ }^{39}$

Zauważmy, że w przypadku Sartre’a zdarzenie spotkania z innym wiąże się $\mathrm{z}$ doświadczeniem przeze mnie mojej własnej przedmiotowej strony. Zmiana, jaką inna podmiotowość wywołuje we mnie, polega więc na tym, że pod jej wpływem ja zostaję ze swej podmiotowości wyzuty i staję się przedmiotem. Szczególnie wyraźnie widać to w przypadku relacji masochistycznej. Inny pokazuje mi granice mojej wolności, ale również ja pokazuję granice jego wolności. Stąd relacje międzypodmiotowe w koncepcji Sartre’a mają charakter konfliktowy.

Wcześniej wspomniane przeze mnie „rozdarcie podmiotu” w filozofii Sartre’a posiada dwa etapy. Pierwszy wymiar wiąże się z zagadnieniem neantyzacji (relacja byt-w-sobie a byt-dla-siebie). Drugi stopień to związek między bytem-dla-siebie a bytem-dla-innego. Na pierwszym poziomie, jak pisze Kowalska: „własne istnienie jest bardziej podstawą swobodnych wyborów i warunkiem władzy nad światem niż ograniczaniem" ${ }^{40}$. Zupełnie inaczej wygląda sytuacja na etapie drugim. Sartre twierdzi, że spotkanie z innym ma tu charakter szoku. Nie konstytuuję innego, ale zderzam się z jego twarzą, bądź odczuwam na sobie jego spojrzenie.

Spotkanie $\mathrm{z}$ innym podmiotem jest według francuskiego filozofa równoznaczne z uprzedmiotowieniem bytu-dla-siebie. Inny jakoś mnie postrzega, więc ja jestem dla niego przedmiotem, co więcej, to właśnie dzięki innemu, ja odkrywam własną przedmiotowość. Można zatem powiedzieć, że podmiot poprzez swobodną neantyzację posiada nieograniczoną wolność. Równocześnie, odkrywając siebie jako przedmiot, doświadcza granic owej wolności, wyznaczonej mu przez innego. Sytuacja ta analogicznie wygląda w relacji odwrotnej. Kiedy ja odzyskuję wolność bycia-dla-siebie i rzucam spojrzenie $\mathrm{w}$ stronę innego, wtedy inny staje się dla mnie przedmiotem. Zatem relacja ja-inny jest nieustannym konfliktem.

\footnotetext{
39 Tamże, s. 495.

${ }^{40}$ M. Kowalska, Dialektyka poza dialektyką, s. 234.
} 


\title{
Bibliografia
}

Kant I., Marzenia jasnowidzacego objaśnione przez marzenia metafizyki, tłum.

M. W. Kozłowski, [w:] I. Kant, Dzieła zebrane, t. 1, Wydawnictwo Naukowe UMK, Toruń 2010.

Kowalska M., Dialektyka poza dialektyka. Od Bataillea do Derridy, Fundacja Aletheia, Warszawa 2000.

Levinas E., Odkrywając egzystencje z Husserlem i Heideggerem, tłum. E. Sowa, Wyd. IFiS PAN, Warszawa 2008.

Levinas E., O uciekaniu, tłum. A. Czarnacka, Wyd. IFiS PAN, Warszawa 2007.

Rowley H., Tête à Tête. Opowieść o Simone de Beauvoir i Jean-Paulu Sartrze, tłum. J. Kalińska, Wyd. Jacek Santorski, Warszawa 2006.

Sartre J. P., Byt i nicość. Zarys ontologii fenomenologicznej, tłum. zbiorowe, Wyd. Zielona Sowa, Kraków 2007.

Sartre J. P., Intencjonalność jako kategoria egzystencjalna, tłum. A. Milecki, [w:] Filozofia egzystencjalna, red. L. Kołakowski, K. Pomian, PWN, Warszawa 1965.

Sartre J. P., Mdłości, tłum. J. Trznadel, Wyd. Zielona Sowa, Kraków 2005.

Sartre J., P., Szkic o teorii emocji, tłum. R. Abramciów, Kraków 2006.

Święcicka K., Husserl, Myśli i ludzie. Wiedza Powszechna, Warszawa 1993.

Tischner J., Filozofia dramatu, Znak, Kraków 2006.

Żelazny M., Filozofia i psychologia egzystencjalna, Wydawnictwo Naukowe UMK, Toruń 2011.

\begin{abstract}
Can I Know the Other?

The Problem of Inter-subjective Relations in Jean Paul Sartre's Philosophy

The question of the relation between two different subjects is a crucial one in J. P. Sartre's philosophy. His conception is based on claim that this relation has existential (not cognitive) character. The essence of a meeting is the otherness of the other. According to Sartre, meeting the other is always a kind of shock. Furthermore, in Sartre opinion relation between me and the other is based on a constant conflict.
\end{abstract}

Key words: Me, other, relation, subjectivity, conflict, liberty, look, Sartre 